\title{
Metallothionein mRNA induction is correlated with the decrease of DNA strand breaks in cadmium exposed zebra mussels
}

\author{
Françoise Vincent-Hubert $^{\mathrm{a}, \mathrm{b}, *}$, Amélie Châtel ${ }^{\mathrm{a}, \mathrm{b}}$, Catherine Gourlay-Francé $^{\mathrm{b}, \mathrm{c}}$
}

\begin{abstract}
a IRSTEA Unité de Recherches Hydrosystèmes et Bioprocédés, 1 rue Pierre-Gilles de Gennes, CS 10030, 92761 Antony Cedex - France

${ }^{b}$ IFREMER, Laboratoire de virologie - LNR, rue de l'île d'Yeu, BP 21105, F 44311 Nantes Cedex 03 France

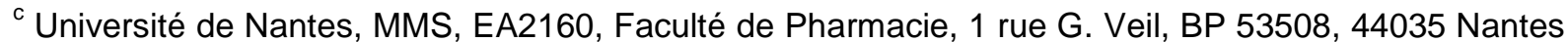
Cedex 1, France
\end{abstract}

*: Corresponding author : Françoise Vincent-Hubert, email address : francoise.vincent@ifremer.fr

\begin{abstract}
:
We have previously shown that cadmium $(\mathrm{Cd})$ and Benzo[a]pyrene $(\mathrm{BaP})$ induced early DNA damages in zebra mussels, and that the level of DNA strand breaks (SB) returned to a basal level after 3 days of exposure to $\mathrm{Cd}$. The aim of the present study was to go further in the mechanisms of $\mathrm{Cd}$ and BaP detoxification. For that purpose, expression of genes encoding for metallothionein (MT), Aryl Hydrocarbon Receptor (AHR), P-gP, catalase, glutathione S-transferase and Heat shock protein 70 (HSP70) proteins have been measured using RT-qPCR. Data reported here show that Cd is a strong inducer of MT and HSP70 genes, and that BaP is a strong inducer of P-gP and AHR genes. Exposure to $\mathrm{Cd}$ and $\mathrm{BaP}$ resulted in moderate changes in antioxidant enzymes mRNA. Since the increase of MT mRNA occured when the DNA SB level returned to its basal level, we can suggest that MT is implicated in cadmium detoxification.
\end{abstract}

\section{Highlights}

cadmium (Cd) and Benzo[a]pyrene (BaP) induced DNA damages in zebra mussels. $\rightarrow \mathrm{Cd}$ is a strong inducer of Metallothionein (MT) and HSP70 genes. Metallothionein might be implicated in cadmium detoxification. $\mathrm{BaP}$ is a strong inducer of $\mathrm{P}-\mathrm{gP}$ and $\mathrm{AHR}$ genes. $\mathrm{Cd}$ and $\mathrm{BaP}$ induced in moderate changes in antioxidant enzymes mRNA.

Keywords : Benzo[a]pyrene ; cadmium-metallothionein ; Aryl Hydrocarbon Receptor ; antioxidant enzymes ; RT ; qPCR 


\section{Introduction}

The zebra mussel is an organism of choice for the monitoring of metallic and organic contaminants in freshwater ecosystems [1-4]. The sensitivity of zebra mussels to genotoxic contaminants has been demonstrated through the induction of micronuclei, DNA strandbreaks and DNA adducts [5-9]. Similarly, field studies revealed that DNA damages were higher in mussels from polluted sites compared with reference site [10, 11]. However, little is know about the regulation of proteins implicated in detoxification following DNA strand breaks.

Recently, gene expression profiles of proteins implicated in detoxification and stress were analyzed in zebra mussels exposed to cadmium and xenobiotics (metoprolol and levonorgestrel). These first observations improved our knowledge in the regulation of these genes [12-14]. These genes encode for proteins that are reliable biomarkers in field and laboratory exposures to contaminants, including metals and organic pollutants. MT has been suggested to be key elements causing the retention of $\mathrm{Cd}$ in mussels [15]. High level of MT mRNA was observed in many organisms exposed to cadmium, including zebra mussel [16]. Heat shock proteins are widespread in plants, bacteria and animals and belong to chaperone proteins, which are important for protein folding, protein transport and cell stabilisation [17, 18]). Superoxide dismutase (SOD) and Catalase (CAT) are antioxidant enzymes and reliable biomarkers of reactive oxygen species [19], SOD is responsible for the reduction of the superoxide radical into hydrogen peroxide, and CAT for catalysing hydrogen peroxide to water. Glutathione S-transferase gene (GST) encodes a phase II metabolizing enzyme known to catalyze the conjugation of glutathione with various electrophilic substances and plays a role preventing oxidative damages [20]. The P-glycoprotein, P-gp, is a member of the multidrug transporter proteins that are ATP dependent proteins which efflux a variety of moderately hydrophobic compounds out of cells [21-23]. The HSP70, which is involved in the processing of misfolded proteins due to different kinds of stress, is used as a very 
74 general ecotoxicological endpoint for protein damage and subsequent protective 75 mechanisms [24].

76 The data presented here are the second part of a article published earlier in which we 77 first shown that zebra mussels exposed to environmentaly relevant concentrations of $\mathrm{Cd}$ and 78 BaP displayed DNA damages [25]. Cadmium, as well as Benzo[a]pyrene (BaP), are model environmental contaminants, classified as a human carcinogen by the IARC [26]. Cd shows a co-genotoxic effects in combination with other mutagenic agents such as UV light, alkylating agents and $\mathrm{B}[\mathrm{a}] \mathrm{P}$ in mammalian cells. Cadmium is assumed to be a weak genotoxicant that amplifies the genotoxic effect of $B[a] P[27,28]$. Therefore, based on these

83 studies, we wanted to determine whether Cd could have the same effect in mussels. We 84 have shown that $\mathrm{Cd}$ induced early DNA damages (DNA strand break and DNA oxidation), and that $\mathrm{BaP}$ induced DNA damages only on the third day of exposure. The most surprising is that the level of DNA returned to the basal level despite the continued presence of cadmium.

The aim of the present study was to go further in the mechanisms of $\mathrm{Cd}$ and $\mathrm{BaP}$ detoxification to determine why the level of DNA stand breaks return to its basal level. For that purpose, we measured gene expression of several proteins described to be involved in detoxification, such as metallothionein, AHR, P-gP, catalase, SOD and glutathione Stransferase. HSP70 gene expression was also measured as a general indicator of stress. 


\subsection{Chemical reagents}

$104 \mathrm{CdCl}_{2}, \mathrm{BaP}, \mathrm{DMSO}$, agarose, trypan-blue and PBS were purchased from Sigma (France).

\subsection{Mussel sampling and maintenance conditions}

Adult specimens of the zebra mussel Dreissena polymorpha (shell length $25 \pm 2 \mathrm{~mm}$ ) were collected in the East channel (Commercy, France), which is a reference site. Cd concentration in mussels is in good agreement with those usually found in bivalves from clean waters [29]; BaP was not detected [11, 30]. Mussels were detached from the rock by cutting their byssus threads and carried to the laboratory in their original water. The mussels were randomly placed in a $20-\mathrm{L}$ aerated tank with about 100 specimens each, and acclimatized to Valvert mineral water and temperature $\left(15^{\circ} \mathrm{C}\right)$, a day/night lighting system was applied. The mussels were fed every 3 days with algae (Pseudokirchneriella subcapitata) and the water was changed every 2 days. The animals that had not become attached to the tank were removed. The mussels were maintained in the above conditions for 8 days before the start of treatment since it was demonstrated that this time is needed to reach a baseline level of DNA damage [31].

\subsection{In vivo exposure of zebra mussels}

121 We chose two genotoxicants with different modes of genotoxic action: benzo[a]pyrene, which

122 prevalent mechanism of action relies on DNA adducts, and cadmium for its pro-oxidant

123 properties and its role in the inhibition of DNA repair. In order to work with more environmentally realistic concentrations, the $\mathrm{Cd}$ and $\mathrm{BaP}$ concentrations used here were lowlevel concentrations equal to the lowest genotoxic concentration published for zebra mussels

126 or marine mussels [6, 32]. A stock solution of $\mathrm{CdCl}_{2}$ and $\mathrm{BaP}$ was prepared in water or pure

127 DMSO, respectively. Preliminary experiments showed that DMSO in water $(0.001 \%)$ did not 128 induce genotoxic effects. 
129 Following overnight equilibrium of tanks with chemical compounds to avoid adsorption to the

130 wall of the tank, mussels were added after renewing the water. Ten mussels were exposed

131 to $\mathrm{BaP}$ at $10 \mu \mathrm{g} / \mathrm{L}, \mathrm{Cd}$ at $10 \mu \mathrm{g} / \mathrm{L}$ and to a combination of $\mathrm{Cd}(10 \mu \mathrm{g} / \mathrm{L})$ and $\mathrm{BaP}(1 \mu \mathrm{g} / \mathrm{L})$

132 dissolved in $8 \mathrm{~L}$ of water for 11 days at $15^{\circ} \mathrm{C}$. In order to maintain the chemical concentration

133 constant, water was renewed every 2 days and then contaminated again with chemicals. For

134 each parameters analyzed, four mussels were sacrificed after $0,12 \mathrm{~h}, 24 \mathrm{~h}$ and 3,5 and 11

135 days of exposure for further analysis (bioaccumulation, DNA damages and gene expression).

136 Cadmium bioaccumulation, DNA damages and nuclear abnormalities data were already

137 published [25]. Gills of 4 mussels were pooled and frozen for gene expression analysis.

\subsection{RNA extraction, RT-PCR and $q R T-P C R$ analysis}

140 Total RNA was isolated from frozen gills of Dreissena polymorpha using the phenolic reagent

141 TRIZOL (Invitrogen, France). RNA concentration and purity was measured by 142 spectrophotometric absorption (260/280 and 230/280 ratio), RNA quality was checked with 143 denaturing gel electrophoresis. First strand cDNA synthesis was carried out on $1 \mu \mathrm{g}$ of total 144 RNA extract with oligo-dT primers according to Improm II Reverse Transcriptase kit 145 (Promega, France).

146 Real-time PCR assays for Ribosomal protein S3 (S3), Catalase (CAT), superoxide 147 dismutase (SOD), Glutathion S-transferase (GST), Metallothionein (MT), Heat-shock protein 14870 (HSP70), Aryl Hydrocarbon receptor (AHR), and P-gp were run in a LightCycler 480 Real 149 Time PCR System (Biorad) using SYBR Green Power Master Mix (Invitrogen, France). PCR 150 reactions and primers pairs were those published by [12] except for Ribosomal protein S3 151 [14]. Determination of the transcript abundances in individual sample was conducted with the 152 comparative $\mathrm{C}_{\mathrm{T}}$ method $\left(\Delta \Delta \mathrm{C}_{\mathrm{T}}\right)$ in consideration of a calibrator sample (control sample). 153 Samples were normalized to Ribosomal S3 gene due to its constant expression [14]. At the 154 end of each PCR reaction a melting curve analysis was carried out to proof assay specificity.

155 PCR efficiency values for reference and tested genes were calculated as described [33], and 156 assumed to be close to $100 \%$ from these calculations. 
157

158

159

$160 \quad 2.5$ Statistic analysis

161 RT-qPCR results are given as mean values \pm S.D. of 3 values (4 mussels per condition

162 pooled and 3 repetitions of each test). The calculated values were compared among different

163 groups (model agents' concentration) using an Analysis of Variance (ANOVA) followed by a

164 Tukey post hoc test. Three levels were considered significant: $p<0.05\left({ }^{\star}\right), p<0.01\left(^{* \star}\right)$ and

$\left.165 \mathrm{p}<0.001{ }^{* * *}\right)$. All statistical analysis was performed with $\mathrm{R}$ software.

166 


\section{Results}

167

168 The data published here are the second part of a study published earlier [25] in which we observed an increase of DNA strand breaks in gill cells of mussel exposed to

170 environnementaly relevant concentrations of $\mathrm{Cd}$ and $\mathrm{BaP}$ (see Table 1, Supporting 171 information). The renewal of the water every 2 days ensured a constant cadmium 172 concentration over the 11-day experiment: $8.27 \pm 0.18$ and $8.23 \pm 0.34 \mu \mathrm{g} / \mathrm{L}$ in $\mathrm{CdCl}_{2}$ and $173 \mathrm{CdCl}_{2}+\mathrm{B}[\mathrm{a}] \mathrm{P}$ media, respectively. Bioaccumulation of cadmium in soft tissues of mussels exposed to $\mathrm{CdCl}_{2}(10 \mu \mathrm{g} / \mathrm{L})$ or $\mathrm{CdCl}_{2}+\mathrm{B}[\mathrm{a}] \mathrm{P}(10 \mu \mathrm{g} / \mathrm{L}+1 \mu \mathrm{g} / \mathrm{L})$ increased over the 11 days of exposure from $9 \mu \mathrm{g} / \mathrm{g} \mathrm{dw}$ after $24 \mathrm{hr}$ of exposure to $45 \mu \mathrm{g} / \mathrm{g} \mathrm{dw}$ at the end on day 11 [25].

Strongest changes in the expression of detoxification genes were found for MT, HSP70 and P-gp genes. A significant increased was noticed, up to 6.5, 10 and 17 fold, respectively after 5 days of exposure to BaP for P-gp ( $p<0.001)$, after 3 days of exposure to $\mathrm{Cd}$ and $\mathrm{Cd}+\mathrm{BaP}$ for MT ( $p<0.001)$, and after 11 days of exposure to Cd for HSP70 $(p<0.001)$.

181 It is important to note that DNA strand breaks induced by Cd return to the basal level when

182 MT gene expression started to increase. Indeed, MT mRNA expression increased gradually 183 from day 3 until day 11 . The same trend was observed when mussels were exposed to $184 \mathrm{Cd}+\mathrm{BaP}$. The presence of $\mathrm{BaP}$ in the mixture does not inhibit the effect of $\mathrm{Cd}$ on MT gene 185 induction.

186 Also, as expected, BaP is as well a strong inducer of AHR gene in zebra mussel, as we 187 observed an early and transient increase of the AHR mRNA expression as soon as $12 \mathrm{hr}$ 188 after the beginning of the exposure to $\mathrm{BaP}$ alone $(\mathrm{p}<0.01)$. and to the mixture $\mathrm{Cd}+\mathrm{BaP}$ $189(\mathrm{p}<0.05)$ AHR mRNA expression was slightly decreased at day 1 and day 5 , respectively in $190 \mathrm{BaP}(\mathrm{p}<0.05), \mathrm{Cd}+\mathrm{BaP}(\mathrm{p}<0.001)$ and in $\mathrm{Cd}$ exposed

191 mussels $(p<0.01)$.

192 P-gp was slightly up-regulated by $\mathrm{Cd}$ and BaP during the 11 days of exposure, with the 193 strongest induction at day 5 in Cd exposed mussels. 
194 HSP70 was slightly up-regulated during the first days of exposure to $\mathrm{Cd}$, and strongly up-

195 regulated at day 11 as already mentioned, indicating protein damage.

196 In contrast, the effect of Cd an BaP was less important on SOD, GST and CAT mRNA levels.

197 More precisely, CAT mRNA was two times decreased after $12 \mathrm{hr}$ of exposure in BaP

198 exposed mussels $(p<0.01)$ and after $24 \mathrm{hr}(p<0.001)$ in $C d$ and $C d+B a P$ exposed mussels

199 compared to control. On the contrary, CAT gene was up-regulated, two times, after 3 and 5

200 days of exposure, respectively in $\mathrm{Cd}+\mathrm{BaP}$ and $\mathrm{Cd}$ exposed mussels.

201 GST mRNA was 1.5 time increased after $12 \mathrm{~h}$ of exposure to $\mathrm{Cd}+\mathrm{BaP}$, and significantly

202 decrease after 3 days and 11 days of exposure to $\mathrm{Cd}, \mathrm{BaP}$ and $\mathrm{Cd}+\mathrm{BaP}$.

203 SOD mRNA was about two times decreased in Cd exposed mussels from the first day until

204 the eleventh day but this was significant only on days 3 and 5. SOD mRNA was 1.5 times

205 increased after $12 \mathrm{hr}, 5$ and 11 days of exposure to $C d+B a P(p<0.001$ and $p<0.05)$ and after

2063 days and 11 days of exposure to $\mathrm{BaP}(\mathrm{p}<0.001)$.

207

208

209

210

211 


\section{1}

212

213 The present study is the second part of a study in which we reported early genotoxic effects

\section{Discussion} of $\mathrm{Cd}$ and $\mathrm{BaP}$ in gill cells of zebra mussels. We wanted to determine whether stress-related genes and detoxification genes are regulated at the transcriptional level in the hours following genotoxic damage in gills.

Tissue-specific differences in gene expression following exposure to metals $(\mathrm{Cd}$, $\mathrm{Cu}, \mathrm{Hg}$ ) and BaP have been published previously [14] [34], hence we focused here on gills in the hours following genotoxic damage. Indeed similar patterns of mRNA abundance were observed between gills an digestive gland in $\mathrm{Cd}$ exposed mussels, while in $\mathrm{BaP}$ exposed mussels, we noticed an early induction of $H S P 70, \mathrm{PgP}, A H R$ and SOD mRNA levels in the gills compared to the digestive glands. Therefore, it appears from these studies that gill tissue represents an interesting model to investigate the molecular mechanisms of detoxification [34].

We show here that, at environmentally relevant concentrations, $\mathrm{Cd}$ is a strong inducer of MT and HSP genes, and that $\mathrm{BaP}$ is a strong inducer of $\mathrm{PgP}$ and $\mathrm{AHR}$ genes. Exposure to $\mathrm{Cd}$ and $\mathrm{BaP}$ resulted in moderate changes in antioxidant enzymes mRNA. The mRNA level of metallothionein increases when the level of DNA strand breaks returned to its basal level, which is probably the most interesting result of this study

We confirmed that $\mathrm{Cd}(10 \mu \mathrm{g} / \mathrm{L})$ is a strong inducer of MT gene, 8 times more than control. Indeed, zebra mussels accumulate Cd at water concentrations as low as $9 \mu \mathrm{g} / \mathrm{liter}$, excluding the possibility of a homeostatic control [35], and as a consequence, MT protein is induced [36]. Therefore it appears that MT mRNA induction and MT protein induction are early increase in zebra mussel as Lecoeur et al. [37] observed an early increase of total MT biosynthesis after exposure to Cd $(2-20 \mu \mathrm{g} / \mathrm{L})$. Only one isoform of MT gene has been reported for zebra mussel, the Dp MT [38]. Engelken and Hildebrandt [38] first shown that cadmium was an inducer of MT gene but this was for elevated concentration of cadmium; afterwards, an increase of this gene expression has also been observed for lower Cd concentrations [14, 38-40] [16]. Cadmium 
increases the synthesis rate of metallothionein messenger-RNA via transcriptional activation

240 of metal-responsive factors located in the upstream region of MT genes [41]. We used here

241 cadmium at environmentally relevant concentrations, measured in rivers strongly impacted

242 by mining activities [40].

243 Our data provide evidence on the exposure time required for the induction of MT gene by

244 cadmium: MT mRNA level gradually increases from the third day until the eleventh day of

245 exposure suggesting that during the first three days, the physiological concentration of MT

246 protein was not high enough to adsorb the Cd. A time-dependent increase was also reported

247 but for higher concentration of cadmium $(20 \mu \mathrm{g} / \mathrm{L})$ [14].

248 Interestingly, the increase of MT mRNA occurs as the DNA strand break level return to its

249 basal level, suggesting that DNA repair was efficient. However as a constant concentration of

250 cadmium in the water and an increase of bioaccumulated cadmium were measured, these

251 data also suggest a decrease in Cd bioavailability. Indeed, the MT protein concentration is

252 probably higher on the third day, compared to the first day; a higher level of MT protein can

253 lead to a decreased bioavailability of $\mathrm{Cd}$ and, as a consequence, $\mathrm{Cd}$ induced DNA damage

254 could be decreased too. Similar observations were recently reported by Qu \& Waalkes [42];

255 these authors demonstrated that MT-competent cells activate MT in response to Cd, while

256 MT-deficient cells adapt to Cd primarily by turning on oxidant response systems.

257 Cd is known to induce reactive oxygen species (ROS) which in turn lead to DNA strand

258 breaks and Oxidative DNA damage [43], an effect that we also observed with zebra mussels

259 [25]. MT has two major functions in Cd toxicity inhibition: (i) MT detoxicates the metal by

260 direct binding and (ii) the cysteines in MT appear able to react directly with ROS, thus MT

261 may also act as an antioxidant independently of metal sequestration [45, 46]. Our data

262 highlight the role of MT in the inhibition of Cd genotoxicity.

263 One of the known protective mechanisms that aquatic animals have developed in

264 response to stresses is the induction of HSPs. We observed that Cd is a strong inducer of

265 HSP70 gene, on the contrary to Navaro et al. [14] who reported HSP70 gene induction only

266 in the digestive gland. Interestingly the strongest up-regulation of HSP mRNA, seventeen 
267 times more than control, was observed after 11 days of constant exposure to Cd. HSP70 are

268 protein chaperones that are induced by various environmental stressors including organic 269 pollutants [47] and metals such as $\mathrm{Hg}, \mathrm{Cu}, \mathrm{Cd}$ [14]. HSP acts to prevent protein aggregation 270 and to maintain functional conformations. This transcriptional regulation of HSP70 is 271 probably necessary to enhance the tolerance to cadmium, as elevated levels of HSPs have

272 been proven to protect against the negative impact of metals on protein integrity $[48,49]$.

273 We confirmed that $\mathrm{BaP}(4.4 \mathrm{nM})$ is an inducer of HSP70 as we observed previously [34]. The

274 regulation of $\mathrm{HSP} 70$ gene in response to BaP remains unclear. For example, high 275 concentration of $\mathrm{BaP}(10 \mu \mathrm{M})$ suppress the transcription of HSP70 gene in human 276 endothelial cell [50], and BaP $(1 \mu \mathrm{M})$ up-regulate HPS70 mRNA in bronchial cells, suggesting 277 a potential role of HSP70 in the NER DNA repair [51].

278 We observed that Cd up-regulated both MT and HSP70 genes. It is well known that 279 HSP70 and MT promoters possess anti-oxidant response element (ARE) which may provide 280 a mechanistic explanation to this correlated response $[52,53]$. Cd has been described to 281 induce HSP70 and MT proteins in mammals and oysters [54, 55].

282 In Mammals, Cytochrome P450 enzymes are important in the metabolization of 283 xenobiotics, such as PAHs [56]). Induction of CYP1 is mediated mainly through a specific 284 cytosolic receptor, the aryl hydrocarbon receptor (AHR). Activated AHR is also a transcription 285 factor of other genes that encode phase I and II xenobiotic metabolizing enzymes [57]. Our 286 data confirmed that $\mathrm{BaP}$ is a strong inducer of AHR gene as we recently observed [34]. AHR 287 mRNA induction was lower in $\mathrm{Cd}+\mathrm{BaP}$ exposed mussels, suggesting an interaction between $288 \mathrm{Cd}$ and $\mathrm{BaP}$, as observed for fish and Human hepatocytes. Indeed, it has been shown that $289 \mathrm{Cd}$ decreases the induction of $\mathrm{AHR}$ by $\mathrm{BaP}$ in that biological models $[58,59]$. AHR seems to 290 be implicated in the detoxification of $\mathrm{BaP}$ in zebra mussels; as the AHR serves as a 291 transcription factor for enzymes of the CYP450 family, our data suggest that BaP is 292 metabolised by CYP450, as it was recently proposed for pharmaceutical compounds [12].

293 We observed that exposure to $\mathrm{Cd}$ and BaP resulted in moderate changes in 294 antioxidant enzymes, characterized by a slight decrease of mRNA levels of SOD, GST and 
CAT genes, which suggest a moderate regulation of these genes at the transcriptional level.

296 It is known that $\mathrm{Cd}$ induced a depletion of cellular GSH, which could explain the slight decrease of anti-oxidant enzymes mRNA level. We previously observed that when BaP was added in aquaria containing zebra mussels two times a day, animals presented an increase in GST, CAT and SOD mRNA levels after $12 \mathrm{~h}$ of exposure. In the present study, the same concentration of $\mathrm{BaP}$ (renewed every two days) did not induce significant increase of mRNA levels of those genes. As CAT, SOD and GST are the first enzymes induced after animal exposure to xenobiotics, we can suggest that their mRNA levels probably increased before the twelfth hourof exposure which would explain that we have not been able to detect their increase. At the protein levels, data of the literature also appeared to be contradictory, hence it is suggested that catalase activity was dependent on the animal tested, the nature of chemicals and the intensity of exposure [60], which is confirmed in the present study. Hoarau et al. [61] observed an inhibition of GST gene expression after marine mussel exposure to $\mathrm{BaP}$ whereas mussels collected in a site highly contaminated with PAH exhibited an induction of its expression.

The increase of P-gp expression observed in the present study is not surprising as this protein is implicated in non specific excretion of xenobiotics, metabolites as well as waste products derived from cell damage $[62,63]$. The induction of P-gp by BaP was first reported in Caco-2 cells $[64,65]$. The inducilbility of P-gp by BaP was also observed in blue mussels at the protein level [65] and at the mRNA level [66]; in zebra mussel, we recently shown an increase at the transcriptional level [34].

In conclusion, gill tissue represents an interesting model to investigate the expression of genes encoding for stress related proteins. $\mathrm{Cd}$ and $\mathrm{BaP}$ induced a regulation at the transcriptional level of genes implicated in either metabolism or detoxification such as $\mathrm{AH}-\mathrm{R}$,

320 HSP70, P-gp and MT. Cd seems to decrease the induction of AHR by BaP as already

321 described for fish and human hepatocytes. In Cd exposed mussels, the up-regulation of MT

322 mRNA is correlated with the restoration of the DNA SB basal level suggesting that MT is 
323 implicated in cadmium detoxification. Future studies need to be done to clarify the interaction

324 of metals and PAHs on AHR gene expression.

325

326

327 Conflict of interest:

328 The authors declare that there are no conflicts of interest.

329

330 Acknowledgements

331 The authors thank the PIREN-Seine program and the ONEMA for financial support.

332 
Figure captions

333

334 Figure 1: Relative mRNA expression genes

335 mRNA expression of genes in gills of zebra mussels exposed to $\mathrm{Cd}(10 \mu \mathrm{g} / \mathrm{L}), \mathrm{BaP}(10 \mu \mathrm{g} / \mathrm{L})$

336 and $\mathrm{Cd}+\mathrm{BaP}(10 \mu \mathrm{g} / \mathrm{L}, 1 \mu \mathrm{g} / \mathrm{L})$ for $12 \mathrm{hr}, 24 \mathrm{hr}, 3,5$ and 11 days. Determination of the

337 transcript abundances in individual sample was conducted with the comparative $\mathrm{C}_{\mathrm{T}}$ method

$338\left(\Delta \Delta \mathrm{C}_{\mathrm{T}}\right)$ in consideration of a calibrator sample (control sample). Samples were normalized to

339 Ribosomal S3 gene due to its constant expression. Results (mean values \pm S.D.) were

340 compared among different groups using an ANOVA followed by a Tukey post hoc test. Three

341 levels were considered significant: $p<0.05\left(^{*}\right), p<0.01\left(^{* *}\right)$ and $\left.p<0.001{ }^{* * *}\right)$.

342 A: metallothionein (MT), P-glycoproteion (P-gp), Aryl hydrocarbon receptor (AHR) and Heat 343 shock protein 70 (HSP70)

344 B: superoxide dismutase (SOD), Glutathion S transferase (GST) and catalase (CAT)

Supporting information :

350 Table 1:Tail DNA (\%) in gill cell comets of Dreissena polymorpha

351 DNA strand breaks were measured with the comet assay and expressed as Tail DNA (\%).

352 Control and various treatment groups of mussels were exposed to constant concentration of 353 dissolved $\mathrm{CdCl}_{2}(10 \mu \mathrm{g} / \mathrm{l}), \mathrm{BaP}(10 \mu \mathrm{g} / \mathrm{l})$ and $\mathrm{Cd}+\mathrm{BaP}(\mathrm{Cd}=10 \mu \mathrm{g} / \mathrm{L}, \mathrm{BaP}=1 \mu \mathrm{g} / \mathrm{l})$ for various 354 duration. Tail DNA \% were reported as mean \pm standard error; ${ }^{*} \mathrm{p}<0.05 ;{ }^{* *} \mathrm{p}<0.01$; $355{ }^{* * *} \mathrm{p}<0.001$. 


\section{References}

[1] E. Guerlet, K. Ledy, A. Meyer, L. Giambérini, Towards a validation of a cellular biomarker suite in native and transplanted zebra mussels: A 2-year integrative field study of seasonal and pollution-induced variations, Aquat. Toxicol., 81 (2007) 377-388.

[2] V. Marie, M. Baudrimont, A. Boudou, Cadmium and zinc bioaccumulation and metallothionein response in two freshwater bivalves (Corbicula fluminea and Dreissena polymorpha) transplanted along a polymetallic gradient, Chemosphere, 65 (2006) 609-617.

[3] J. Mersch, M.N. Beauvais, P. Nagel, Induction of micronuclei in haemocytes and gill cells of zebra mussels, Dreissena polymorpha, exposed to clastogens, Mutation Research Genetic Toxicology, 371 (1996) 47-55.

[4] A. Binelli, C. Riva, D. Cogni, A. Provini, Genotoxic effects of p,p-DDT (1,1,1-trichloro-2,2bis-(chlorophenyl) ethane) and its metabolites in Zebra mussel (D. polymorpha) by SCGE assay and micronucleus test, Environ. Mol. Mutagen., 49 (2008) 406-415.

[5] M. Pavlica, G.I.V. Klobucar, N. Mojas, R. Erben, D. Papes, Detection of DNA damage in haemocytes of zebra mussel using comet assay, Mutation Research - Genetic Toxicology and Environmental Mutagenesis, 490 (2001) 209-214.

[6] A. Binelli, C. Riva, D. Cogni, A. Provini, Assessment of the genotoxic potential of benzo(a)pyrene and pp-dichlorodiphenyldichloroethylene in Zebra mussel (Dreissena polymorpha), Mutation Research - Genetic Toxicology and Environmental Mutagenesis, 649 (2008) 135-145.

[7] J. Le Goff, J. Gallois, L. Pelhuet, M.H. Devier, H. Budzinski, D. Pottier, V. Andre, J. Cachot, DNA adduct measurements in zebra mussels, Dreissena polymorpha, Pallas Potential use for genotoxicant biomonitoring of fresh water ecosystems, Aquat. Toxicol., 79 (2006) 55-64.

[8] Y. De Lafontaine, F. Gagné, C. Blaise, G. Costan, P. Gagnon, H.M. Chan, Biomarkers in zebra mussels (Dreissena polymorpha) for the assessment and monitoring of water quality of the St Lawrence River (Canada), Aquat. Toxicol., 50 (2000) 51-71.

[9] A. Binelli, C. Riva, A. Provini, Biomarkers in Zebra mussel for monitoring and quality assessment of Lake Maggiore (Italy), Biomarkers, 12 (2007) 349-368.

[10] A. Bourgeault, C. Gourlay-France, F. Vincent-Hubert, F. Palais, A. Geffard, S. BiagiantiRisbourg, S. Pain-Devin, M.H. Tusseau-Vuillemin, Lessons from a transplantation of zebra mussels into a small urban river: An integrated ecotoxicological assessment, Environmental Toxicology, 25 (2010) 468-478.

[11] C. Michel, A. Bourgeault, C. Gourlay-France, F. Palais, A. Geffard, F. Vincent-Hubert, Seasonal and PAH impact on DNA strand-break levels in gills of transplanted zebra mussels, Ecotoxicol. Environ. Saf., 92 (2013) 18-26.

[12] V. Contardo-Jara, S. Pflugmacher, G. Nützmann, W. Kloas, C. Wiegand, The betareceptor blocker metoprolol alters detoxification processes in the non-target organism Dreissena polymorpha, Environmental Pollution, 158 (2010) 2059-2066.

[13] V. Contardo-Jara, C. Lorenz, S. Pflugmacher, G. Nutzmann, W. Kloas, C. Wiegand, Molecular effects and bioaccumulation of levonorgestrel in the non-target organism Dreissena polymorpha, Environmental Pollution, 159 (2011) 38-44.

[14] A. Navarro, M. Faria, C. Barata, B. Pina, Transcriptional response of stress genes to metal exposure in zebra mussel larvae and adults, Environmental Pollution, 159 (2011) 100107.

[15] A. Viarengo, M.N. Moore, G. Mancinelli, A. Mazzucotelli, R.K. Pipe, Significance of metallothioneins and lysosomes in cadmium toxicity and homeostasis in the digestive gland cells of mussels exposed to the metal in presence or absence of phenanthrene, Marine Environmental Research, 17 (1985) 184-187.

[16] J.P. Bourdineaud, M. Baudrimont, P. Gonzalez, J.L. Moreau, Challenging the model for induction of metallothionein gene expression, Biochimie, 88 (2006) 1787-1792. 
409

410

411

412

413

414

415

416

417

418

419

420

421

422

423

424

425

426

427

428

429

430

431

432

433

434

435

436

437

438

439

440

441

442

443

444

445

446

447

448

449

450

451

452

453

454

455

456

457

458

459

460

461

[17] H.C. Schroder, R. Batel, S. Lauenroth, H.M.A. Hassanein, M. Lacorn, T. Simat, H. Steinhart, W.E.G. Muller, Induction of DNA damage and expression of heat shock protein HSP70 by polychlorinated biphenyls in the marine sponge Suberites domuncula Olivi, Journal of Experimental Marine Biology and Ecology, 233 (1999) 285-300.

[18] I. Werner, D.E. Hinton, Field validation of hsp70 stress proteins as biomarkers in Asian clam (Potamocorbula amurensis): is downregulation an indicator of stress?, Biomarkers, 4 (1999) 473-484.

[19] M.J. Bebianno, F. Geret, P. Hoarau, M.A. Serafim, M.R. Coelho, M. Gnassia-Barelli, M. Romeo, Biomarkers in Ruditapes decussatus: a potential bioindicator species, Biomarkers, 9 (2004) 305-330.

[20] B. Ketterer, B. Coles, D.J. Meyer, The role of glutathione in detoxication Environ. Health Perspect., 49 (1983) 59-69.

[21] S. Pain, M. Parant, Response of multixenobiotic defence mechanism in Dreissena polymorpha exposed to environmental stress, Chemosphere, 52 (2003) 1105-1113.

[22] S. Pain, M. Parant, Identification of multixenobiotic defence mechanism (MXR) background activities in the freshwater bivalve Dreissena polymorpha as reference values for its use as biomarker in contaminated ecosystems, Chemosphere, 67 (2007) 1258-1263.

[23] C. Minier, A. Abarnou, A. Jaouen-Madoulet, A.M. Le Guellec, R. Tutundjian, G. Bocquene, F. Leboulenger, A pollution-monitoring pilot study involving contaminant and biomarker measurements in the Seine Estuary, France, using zebra mussels (Dreissena polymorpha), Environmental Toxicology and Chemistry, 25 (2006) 112-119.

[24] S. Lewis, R.D. Handy, B. Cordi, Z. Billinghurst, M.H. Depledge, Stress proteins (HSP's): Methods of detection and their use as an environmental biomarker, Ecotoxicology, 8 (1999) 351-368.

[25] F. Vincent-Hubert, Arini, A., Gourlay-Francé, C. , Early genotoxic effects in gill cells and hemocytes of dreissena polymorpha exposed to cadmium, and a combination of $\mathrm{B}[\mathrm{a}] \mathrm{P}$ and Cd Mutation Research - Genetic Toxicology and Environmental Mutagenesis, 723 (2011) 2635.

[26] M. Waisberg, P. Joseph, B. Hale, D. Beyersmann, Molecular and cellular mechanisms of cadmium carcinogenesis, Toxicology, 192 (2003) 95-117.

[27] A. Hartmann, G. Speit, Effect of arsenic and cadmium on the persistence of mutageninduced DNA lesions in human cells, Environ. Mol. Mutagen., 27 (1996) 98-104.

[28] S.E. Hook, R.F. Lee, Interactive effects of UV, benzo[a] pyrene, and cadmium on DNA damage and repair in embryos of the grass shrimp Paleomonetes pugio, Marine Environmental Research, 58 (2004) 735-739.

[29] J. Mersch, E. Morhain, C. Mouvet, Laboratory accumulation and depuration of copper and cadmium in the freshwater mussel Dreissena polymorpha and the aquatic moss Rhynchostegium riparioides, Chemosphere, 27 (1993) 1475-1485.

[30] A. Bourgeault, C. Gourlay-France, C. Priadi, S. Ayrault, M.H. Tusseau-Vuillemin, Bioavailability of particulate metal to zebra mussels: Biodynamic modelling shows that assimilation efficiencies are site-specific, Environmental Pollution, 159 (2011) 3381-3389.

[31] I.V. Villela, I.M. de Oliveira, J. da Silva, J.A.P. Henriques, DNA damage and repair in haemolymph cells of golden mussel (Limnoperna fortunei) exposed to environmental contaminants, Mutation Research - Genetic Toxicology and Environmental Mutagenesis, 605 (2006) 78-86.

[32] C. Emmanouil, T.M.T. Sheehan, J.K. Chipman, Macromolecule oxidation and DNA repair in mussel (Mytilus edulis L.) gill following exposure to $\mathrm{Cd}$ and $\mathrm{Cr}(\mathrm{VI})$, Aquat. Toxicol., 82 (2007) 27-35.

[33] M.W. Pfaffl, A new mathematical model for relative quantification in real-time RT-PCR, Nucleic Acids Res., 29 (2001).

[34] A. Chatel, V. Faucet-Marquis, M. Perret, C. Gourlay-France, E. Uher, A. PfohlLeszkowicz, F. Vincent-Hubert, Genotoxicity assessment and detoxification induction in Dreissena polymorpha exposed to benzo a pyrene, Mutagenesis, 27 (2012) 703-711. 
[35] C. Tessier, J.-S. Blais, Determination of Cadmium-Metallothioneins in Zebra Mussels Exposed to Subchronic Concentrations of Cd2+, Ecotoxicol. Environ. Saf., 33 (1996) 246252.

[36] D. Ivankovic, J. Pavicic, V. Beatovic, R.S. Klobucar, G.I.V. Klobucar, Inducibility of Metallothionein Biosynthesis in the Whole Soft Tissue of Zebra Mussels Dreissena polymorpha Exposed to Cadmium, Copper, and Pentachlorophenol, Environmental Toxicology, 25 (2010) 198-211.

[37] S. Lecoeur, B. Videmann, P. Berny, Evaluation of metallothionein as a biomarker of single and combined $\mathrm{Cd} / \mathrm{Cu}$ exposure in Dreissena polymorpha, Environ. Res., 94 (2004) 184-191.

[38] J. Engelken, A. Hildebrandt, cDNA cloning and cadmium-induced expression of metallothionein mRNA in the zebra mussel Dreissena polymorpha, Biochemistry and Cell Biology-Biochimie Et Biologie Cellulaire, 77 (1999) 237-241.

[39] V. Marie, P. Gonzalez, M. Baudrimont, J.-P. Bourdineaud, A. Boudou, Metallothionein response to cadmium and zinc exposures compared in two freshwater bivalves, Dreissena polymorpha and Corbicula fluminea, Biometals, 19 (2006) 399-407.

[40] S. Morin, T.T. Duong, A. Dabrin, A. Coynel, O. Herlory, M. Baudrimont, F. Delmas, G. Durrieu, J. Schäfer, P. Winterton, G. Blanc, M. Coste, Long-term survey of heavy-metal pollution, biofilm contamination and diatom community structure in the Riou Mort watershed, South-West France, Environmental Pollution, 151 (2008) 532-542.

[41] S. Labbe, L. Larouche, D. Mailhot, C. Seguin, Purification of mouse MEP-1, a nuclearprotein which binds to the metal regulatory elements of genes encoding metallothionein, Nucleic Acids Res., 21 (1993) 1549-1554.

[42] W. Qu, J. Pi, M.P. Waalkes, Metallothionein blocks oxidative DNA damage in vitro, Arch. Toxicol., 87 (2013) 311-321.

[43] M. Filipic, T.K. Hei, Mutagenicity of cadmium in mammalian cells: Implication of oxidative DNA damage, Mutation Research - Fundamental and Molecular Mechanisms of Mutagenesis, 546 (2004) 81-91.

[45] N. Chiaverini, M. De Ley, Protective effect of metallothionein on oxidative stress-induced DNA damage, Free Radic. Res., 44 (2010) 605-613.

[46] C.D. Klaassen, J. Liu, B.A. Diwan, Metallothionein protection of cadmium toxicity, Toxicol. Appl. Pharmacol., 238 (2009) 215-220.

[47] I. Boutet, A. Tanguy, D. Moraga, Response of the Pacific oyster Crassostrea gigas to hydrocarbon contamination under experimental conditions, Gene, 329 (2004) 147-157.

[48] T. Haap, H.-R. Koehler, Cadmium tolerance in seven Daphnia magna clones is associated with reduced hsp70 baseline levels and induction, Aquatic Toxicology, 94 (2009) 131-137.

[49] C. Singer, S. Zimmermann, B. Sures, Induction of heat shock proteins (hsp70) in the zebra mussel (Dreissena polymorpha) following exposure to platinum group metals (platinum, palladium and rhodium): Comparison with lead and cadmium exposures, Aquat. Toxicol., 75 (2005) 65-75.

[50] Z. Gong, J. Yang, M. Yang, F. Wang, Q. Wei, R.M. Tanguay, T. Wu, Benzo(a)pyrene inhibits expression of inducible heat shock protein 70 in vascular endothelial cells, Toxicology Letters, 166 (2006) 229-236.

[51] J. Yang, X. Liu, P. Niu, Y. Zou, Y. Duan, Correlations and co-localizations of Hsp70 with XPA, XPG in human bronchial epithelia cells exposed to benzo a pyrene, Toxicology, 265 (2009) 10-14.

[52] F. Haq, M. Mahoney, J. Koropatnick, Signaling events for metallothionein induction, Mutation Research - Fundamental and Molecular Mechanisms of Mutagenesis, 533 (2003) 211-226.

[53] C.I. Jones lii, H. Zhu, S.F. Martin, Z. Han, Y. Li, B.R. Alevriadou, Regulation of antioxidants and phase 2 enzymes by shear-induced reactive oxygen species in endothelial cells, Annals of Biomedical Engineering, 35 (2007) 683-693. 
[54] A. Piano, P. Valbonesi, E. Fabbri, Expression of cytoprotective proteins, heat shock protein 70 and metallothioneins, in tissues of Ostrea edulis exposed to heat and heavy metals, Cell Stress Chaperones, 9 (2004) 134-142.

[55] C. Urani, P. Melchioretto, C. Canevali, G.F. Crosta, Cytotoxicity and induction of protective mechanisms in HepG2 cells exposed to cadmium, Toxicology in Vitro, 19 (2005) 887-892.

520

[56] V. Tamasi, K. Monostory, R.A. Prough, A. Falus, Role of xenobiotic metabolism in cancer: involvement of transcriptional and miRNA regulation of P450s, Cellular and molecular life sciences : CMLS, 68 (2011) 1131-1146.

[57] O. Hankinson, THE ARYL-HYDROCARBON RECEPTOR COMPLEX, Annu. Rev. Pharmacol. Toxicol., 35 (1995) 307-340.

[58] C. Risso-de Faverney, M. Lafaurie, J.P. Girard, R. Rahmani, Effects of heavy metals and 3-methylcholanthrene on expression and induction of CYP1A1 and metallothionein levels in trout (Oncorhynchus mykiss) hepatocyte cultures, Environmental Toxicology and Chemistry, 19 (2000) 2239-2248.

[59] D.D. Vakharia, N. Liu, R. Pause, M. Fasco, E. Bessette, Q.Y. Zhang, L.S. Kaminsky, Effect of metals on polycyclic aromatic hydrocarbon induction of CYP1A1 and CYP1A2 in human hepatocyte cultures, Toxicol. Appl. Pharmacol., 170 (2001) 93-103.

533 [60] F. Regoli, G.W. Winston, S. Gorbi, G. Frenzilli, M. Nigro, I. Corsi, S. Focardi, Integrating 534 enzymatic responses to organic chemical exposure with total oxyradical absorbing capacity Chemistry, 22 (2003) 2120-2129.

[61] P. Hoarau, G. Damiens, M. Romeo, M. Gnassia-Barelli, M.J. Bebianno, Cloning and expression of a GST-pi gene in Mytilus galloprovincialis. Attempt to use the GST-pi transcript as a biomarker of pollution, Comparative Biochemistry and Physiology C-Toxicology \& Pharmacology, 143 (2006) 196-203.

[62] S.M. Bard, Multixenobiotic resistance as a cellular defense mechanism in aquatic organisms, Aquatic Toxicology, 48 (2000) 357-389.

[63] T. Smital, Uptake and efflux transport proteins as integral elements of the cellular detoxification and environmental stress response in aquatic organisms, Comparative Biochemistry and Physiology a-Molecular \& Integrative Physiology, 163 (2012) S2-S2.

[64] N. Sugihara, K. Toyama, A. Michihara, K. Akasaki, H. Tsuji, K. Furuno, Effect of benzo a pyrene on P-glycoprotein-mediated transport in Caco-2 cell monolayer, Toxicology, 223 (2006) 156-165.

[65] A. Prevodnik, K. Lija, T. Bollner, Benzo a pyrene up-regulates the expression of the proliferating cell nuclear antigen (PCNA) and multixenobiotic resistance polyglycoprotein ( $P$ gp) in Baltic Sea blue mussels (Mytilus edulis L.), Comparative Biochemistry and Physiology C-Toxicology \& Pharmacology, 145 (2007) 265-274.

[66] L.J. Dallas, T.P. Bean, A. Turner, B.P. Lyons, A.N. Jha, Oxidative DNA damage may not mediate Ni-induced genotoxicity in marine mussels: Assessment of genotoxic biomarkers and transcriptional responses of key stress genes, Mutation Research-Genetic Toxicology and Environmental Mutagenesis, 754 (2013) 22-31. 
559

\begin{tabular}{|l|l|l|c|l|}
\hline & Control & Cadmium & Cd+BaP & BaP \\
\hline $\mathbf{1 2} \mathbf{~ h r}$ & $15.42 \pm 0.8$ & $24.23 \pm 1.22$ & $13 \pm 0.61$ & $15.56 \pm 0.85$ \\
\hline Day 1 & $10.95 \pm 0.54$ & $22.12 \pm 1.37^{\star * *}$ & $16.92 \pm 0.72^{\star \star *}$ & $14.12 \pm 0.73^{\star *}$ \\
\hline Day 3 & $14.55 \pm 0.88$ & $24.95 \pm 1.17^{* * *}$ & $19.13 \pm 0.99^{* *}$ & $32.39 \pm 1.47^{* * *}$ \\
\hline Day 5 & $11.66 \pm 0.63$ & $11.83 \pm 0.61$ & $13.27 \pm 0.77$ & $14.98 \pm 0.84$ \\
\hline Day 11 & $12.84 \pm 0.68$ & $14.95 \pm 0.88^{*}$ & $12.84 \pm 0.73$ & $15.51 \pm 0.95$ \\
\hline
\end{tabular}

560

561 


\section{$561 \quad$ Highlights}

562

563

564

- cadmium (Cd) and Benzo[a]pyrene (BaP) induced DNA damages in zebra mussels

565

- $\quad$ Cd is a strong inducer of Metallothionein (MT) and HSP70 genes

566

- Metallothionein might be implicated in cadmium detoxification

567

- $\mathrm{BaP}$ is a strong inducer of $\mathrm{P}-\mathrm{gP}$ and $\mathrm{AHR}$ genes

568

- $\mathrm{Cd}$ and $\mathrm{BaP}$ induced in moderate changes in antioxidant enzymes mRNA

569

570 

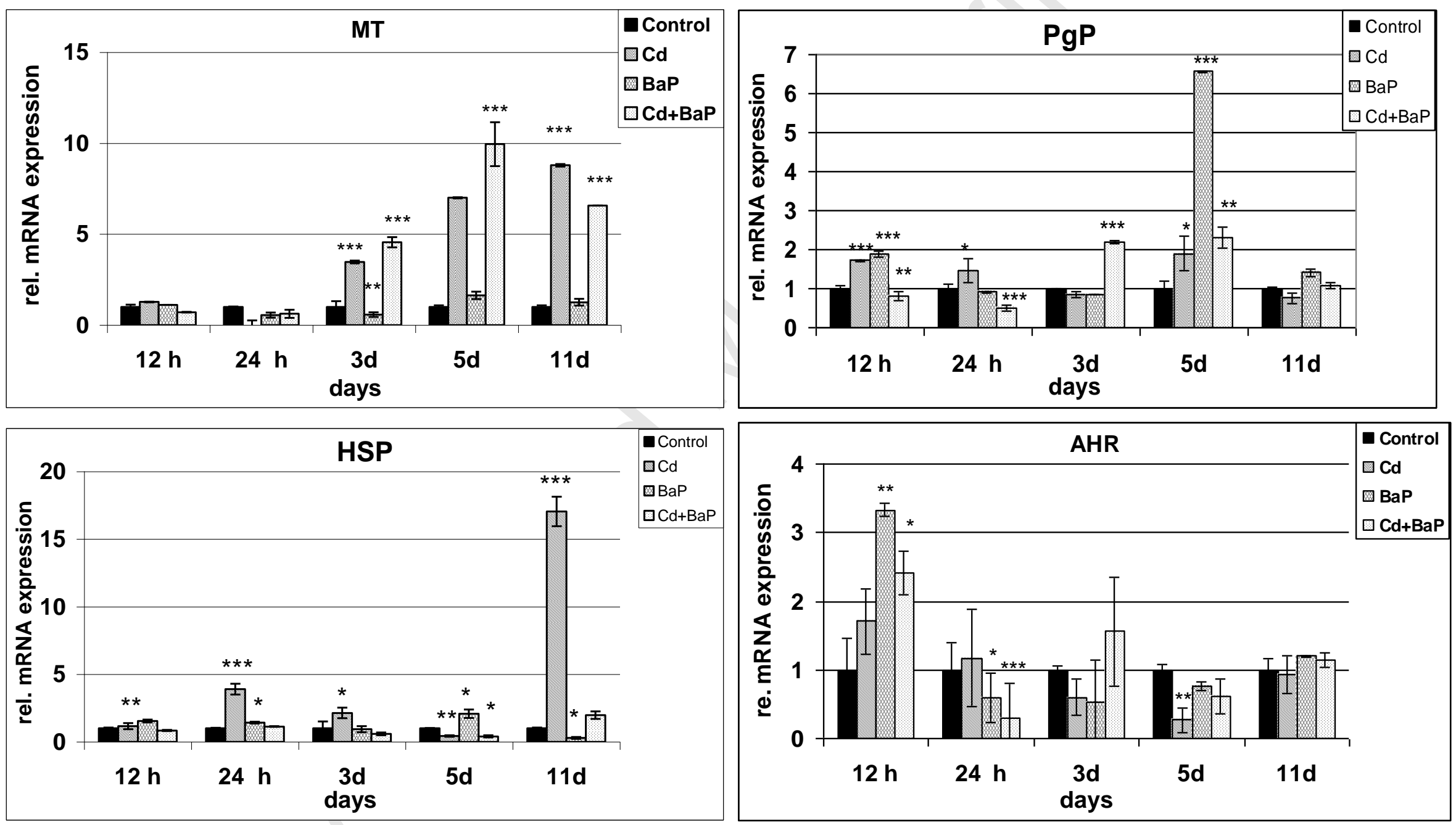

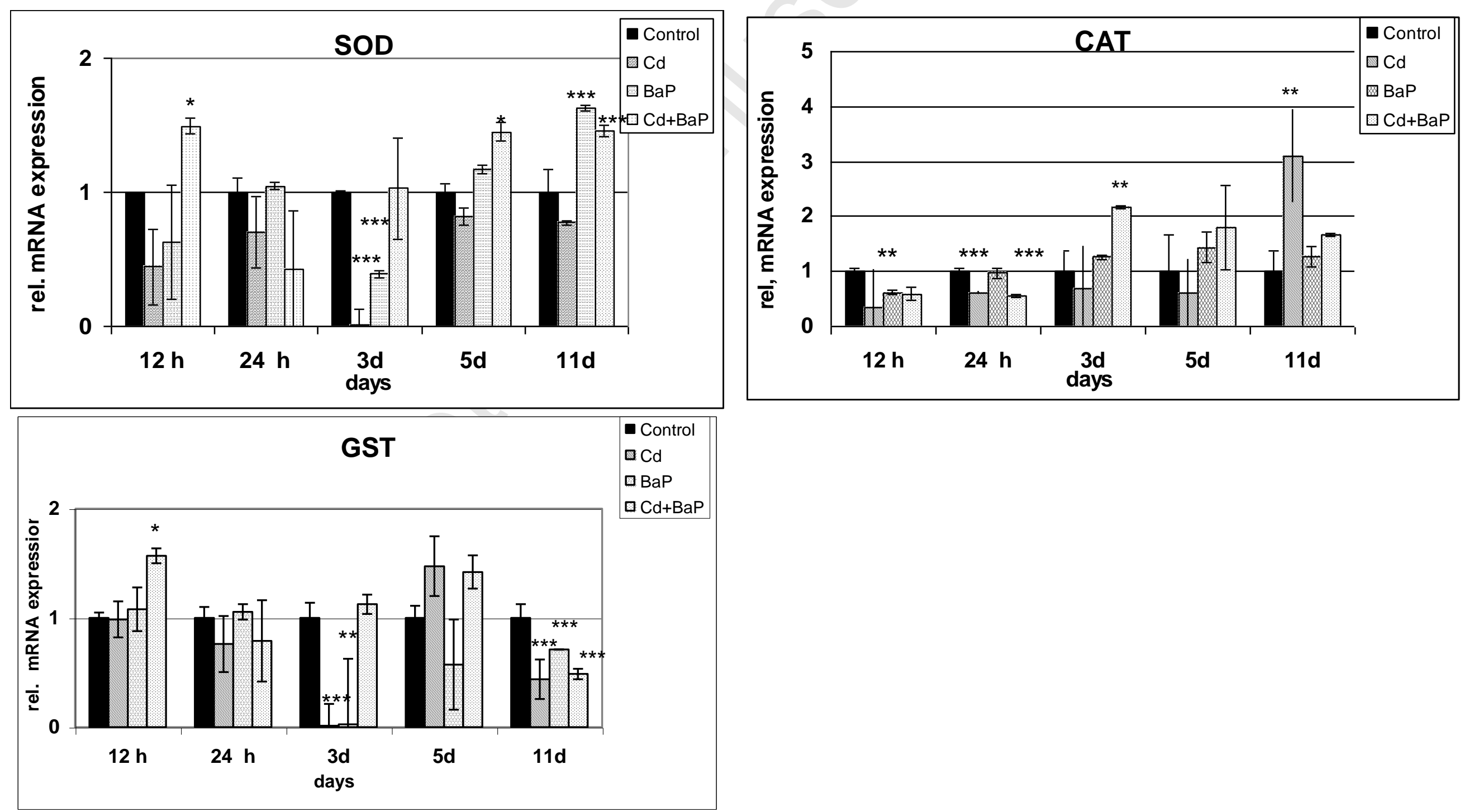